Available online at Dakwah: Jurnal Kajian Dakwah dan Kemasyarakatan http://journal.uinjkt.ac.id/index.php/dakwah

Dakwah: Jurnal Kajian Dakwah dan Kemasyarakatan, 23 (2), 2019, 36-47

\title{
Difusi Inovasi Penggunaan Aplikasi Dakwah: Studi Fenomenologi pada Pengguna Aplikasi Yaumi di Pesantren Luhur Sabilussalam Ciputat
}

Nida Arafat \& Muhamad Zen

\begin{abstract}
This study wants to find out how the diffusion of innovation occurs in Islamic boarding schools Sabilussalam, how these pesantren students decide to jointly use the Yaumi application. An application that provides Islamic features to support the improvement of a Muslim's worship. This study uses a phenomenological research method. Phenomenological research tries to explain the meaning of a concept or phenomenon in experience which is based on the consciousness of several individuals. In the innovation diffusion theory there are two main points, namely the diffusion elements of innovation and the diffusion decision process of innovation. The results of this study indicate that the process of acceptance and use of the Yaumi application by Sabilussalam students has passed the stages mentioned in the innovation diffusion theory.
\end{abstract}

Keywords: diffusion of innovation, Yaumi application, mahasantri

\begin{abstract}
Abstrak
Penelitian ini ingin mengetahui bagaimana difusi inovasi terjadi di pesantren sabilussalam, bagaimana santri-santri pesantren ini memutuskan untuk bersama-sama menggunakan aplikasi Yaumi. Sebuah aplikasi yang menyajikan fitur-fitur Islami untuk mendukung peningkatan ibadah seorang muslim. Penelitian ini menggunakan metode penelitian fenomenologi. Penelitian fenomenologi mencoba menjelaskan makna konsep atau fenomena dalam pengalaman yang didasari oleh kesadaran beberapa individu. Dalam teori difusi inovasi terdapat dua poin utama, yaitu elemen difusi inovasi dan proses putusan difusi inovasi. Hasil penelitian ini menunjukkan proses penerimaan dan penggunaan aplikasi Yaumi oleh santri Sabilussalam telah melewati tahap-tahap yang disebutkan dalam teori difusi inovasi.
\end{abstract}

Kata kunci: difusi inovasi, aplikasi Yaumi, mahasantri

Permalink/DOI: dhttp://doi.org/10.15408/dakwahv23i2.13936

\section{Pendahuluan}

Aktivitas komunikasi yang dialami oleh manusia di era keterbukaan informasi sekarang ini banyak dipengaruhi dengan hadirnya internet. Internet telah mengambil peran di kehidupan manusia baik secara positif maupun negatif. Setelah terhubung dengan internet setiap orang dapat 
menikmati dampak positif dari internet. Diantaranya ialah dengan tersedianya banyak informasi baik secara teks, suara, maupun gambar yang dapat diakses kapanpun dan dimanapun. Menurut Cantoni dan Tardini (2006:189) melihat internet dan perkembangannya dari perspektif komunikasi. Perkembangan internet tidak lain karena internet merupakan media komunikasi manusia yang penting. Keduanya menunjukkan, feature-feature komunikasi internet adalah: Internet memungkinkan konvergensi media sebelumnya karena teks digital bisa dengan mudah dipadukan dengan citra, suara, film, dan grafik digital, teks digital dapat dimodifikasi dan direproduksi dengan sangat mudah, internet seperti halnya juga dengan teknologi untuk penyebarluasan kata-kata, sangat mudah di akses kelompokkelompok besar dalam masyarakat sehingga memunculkan masalah literasi digital. Internet memungkinkan komunikasi yang hampir bersifat seketika untuk komunikasi yang bersifat dua arah atau multi arah pada level global. Dokumen internet membutuhkan hardware dan software yang bisa di akses dan ditafsirkan. ${ }^{1}$

Dengan adanya internet juga memudahkan manusia untuk berinteraksi dengan orang lain tanpa harus merasa terhalang oleh jarak. Menurut Graham, "interaksi atau interactivity merupakan salah satu cara yang berjalan diantara pengguna dan mesin (teknologi) dengan memungkinan para pengguna maupun perangkat saling terhubung secara interaktif. Interaksi merupakan salah satu karakter media siber sebagai alat komunikasi”. Internet sudah menjangkau semua praktik sosial. Mengubah cara berkomunikasi manusia, maka mengubah pula semua praktik sosial. Misalnya cara kita mengakses, menyunting, dan menyebarkan dokumen (berupa teks, film, lagu, citra, atau bentuk lainnya). Selain membawa perubahan dalam pola komunikasi, Internet juga menghadirkan komunitas di dunia maya yang disebut sebagai virtual community. Menurut Rheingold (1995), virtual community merupakan agregasi sosial yang mengambil bentuk di dalam internet di mana semua orang membawa persoalan untuk didiskusikan dalam waktu yang lama, dan melibatkan perasaan atau pemikiran penggunanya dengan relasi yang terbentuk di ruang siber. ${ }^{2}$

Virtual community merupakan komunitas yang terbentuk dari komunikasi yang termediasi oleh komputer (Communication Mediated Computer). Anggota komunitas dapat saling berbagi pengalaman serta menikmati konten yang disediakan pada media siber. Bila pada komunitas di dunia nyata dibutuhkan pertemuan secara tatap muka untuk menjalin komunikasi, namun di komunitas virtual tidaklah diperlukan pertemuan secara tatap muka. Bahkan komunitas cenderung tidak perlu salingmengenal satu sama lain untuk tergabung dalam komunitas. ${ }^{3}$ Virtual communities adalah kesatuan sosial yang muncul dari jaringan sosial ketika sejumlah orang berdiskusi dalam waktu yang cukup lama, dengan perasaan yang cukup untuk hubungan personal di dunia maya (Rheingold, 1993)4.The virtual community, menekankan adanya kualitas dari 
komunitas virtual. Komunitas dapat dibentuk tanpa batasan, melalui Computer Mediated Communication (CMC) yaitu komunikasi dilakukan melalui komputer dalam hal ini dengan internet yang memberikan makna untuk membuat publik aktif dan tergugah untuk mengikuti era kemajuan. Kehadiran teknologi baru, menurut Burnett Robert dan David P Marshal (2003), juga diperlukan untuk membuat masyarakat menjadi lebih baik, dengan kata lain teknologi membangkitkan semangat transformasi budaya, sehingga pembicaraan lebih kepada bagaimana mengembangkan, mengimplementasikan dan mengintegrasikan teknologi baru ke dalam kehidupan kita sehari-hari. Pemahaman ini juga dilakukan oleh komunitas penyimpangan seksual yaitu komunitas Gay dari kalangan remaja yang memiliki prinsip bahwa dengan kemajuan teknologi membangkitkan semangat transformasi budaya baru dengan gaya pacaran dan penyuka sesama jenis yang hal tersebut menuai konflik di masyarakat Indonesia. Teknologi sudah berkembang demikian pesat dalam segala aspek kehidupan kita. Sistem informasi yang saat ini sudah berada pada era digitalisasi telah mengubah cara belajar dari tradisi lisan ke tradisi digital.

Batasan komunitas tidak hanya dipahami sebagai satu kesatuan dalam satu wilayah tertentu yang sifatnya nyata atau ada, tetapi dapat terbentuk dalam suatu area yang sifatnya tidak nyata atau virtual.Nyata dapat diartikan mempunyai hubungan atau interaksi tatap muka, sering bertemu, berdiskusi dan berkelompok. Komunitas seperti ini tetap mereka perlukan sebagai sarana untuk lebih mempererat hubungan karena bagi mereka kedekatan seseorang tidak bisa murni melalui dunia maya. Namun, bukan berarti komunitas tidak dapat terbentuk melalui dunia maya. Kesamaan kepentingan, kesamaan wacana, ide, dan gagasan dapat membawa mereka ke dalam suatu komunitas tersendiri melalui dunia maya. Seperti pada penelitian ini, komunitas Gay terbentuk karena mereka merasa memiliki kesamaan dalam hal misalnya orientasi seksual dengan sesama jenis dan ternyata komunitas ini banyak dari kalangan remaja. Komunitas besar remaja adalah mereka yang ada di usia 16 tahun sampai 24 tahun, siapapun dia dan dimanapun berada. Komunitas akan terbentuk bila ada interaksi di dalamnya. Apapun bentuk interaksi yang dilakukan, tetap saja akan membentuk suatu komunitas. Dapat dipahami bahwa, kita dapat dapat melakukan apa saja sebagaimana halnya di dunia nyata. Hanya saja, kita tidak menyertakan diri kita secara fisik karena komunitas virtual menggunakan kata-kata pada layat untuk bertukar kesenangan, pendapat, saling berbagi sampai dengan saling jatuh cinta dan mendukung secara emosi, mendapat dan kehilangan teman. Komunitas selalu terhubung dengan lokalitas dan batasan geografis.

Seiring dengan semakin bervariasinya konten media dan meningkatnya pengguna media siber. Semakin lama, internet cenderung menjadi sebuah kebutuhan pokok. Internet sebagai penunjang media komunikasi dan informasi yang banyak memberikan 
dampak positif, namun tidak sedikit juga terjadi penyalahgunaan yang justru membawa dampak negatif. Terutama penyalahgunaan yang dilakukan oleh virtual community komunitas Gay penyuka sesama jenis laki-laki melalui media sosial.

Diantaranya dengan munculnya akun twitter bernama @GayUGM yang kurang lebih mencapai 1.802 followers. Akun yang eksis sejak Januari 2013 ini, aktif menyuarakan LGBT melalui tweet dan berkomunikasi dengan akun-akun lainnya. Namun kini akun tersebut telah non-aktif. Banyak diberitakan di internet, hal ini dikarenakan banyak menuai penolakan baik dikalangan masyarakat maupun lingkungan Universitas Gajah Mada (UGM). Kemunculan akun twitter bernama@gaykids_botplg yang secara terang-terangan mengumbar kata-kata vulgar sangat menghawatirkan. Bahkan, mereka juga menampilkan foto dan video seksual yang tak layak dilihat oleh anakanak dibawah umur. Selanjutnya muncul desakan dari Kementerian Komunikasi dan Informatika (KOMINFO) kepada pengelola media-media sosial dan layanan pesan pendek. Agar dihapuskannya emosikon (emoji) atau sticker gay dan lesbian untuk pasar Indonesia, karena hal ini jelas menghawatirkan untuk dikonsumsi masyarakat. Mengingat media siber memiliki jenis-jenis media beragam yang memfasilitasi untuk bertukar informasi baik berupa visual, maupun audio. Di tahun 2009 muncul media sosial Grindr dengan kecanggihan teknologi GPS (Global Positioning System) yang dapat mendeteksi keberadaan gay terdekat melalui smartphone. Bahkan Aplikasi berbasis chatting ini populer di kalangan gay Indonesia. Berdasarkan website resmi Grindr www.Grindr.com terdapat 10 peringkat negara terbesar pengguna Grindr, dan Indonesia mendapat urutan ke-9 sebagai negara pengguna Grindr aktif. 5

Sebuah layanan berbasis Internet, memudahkan pengguna untuk membuat profil diri yang kemudian digunakan untuk saling menghubungi dan dihubungi pengguna lain. Grindr sebagai Online dating, dianggap menarik karena adanya kontrol dari pengguna untuk mengatur sendiri apa yang ingin mereka lakukan melalui media tersebut. terdapat tiga alasan mengapa banyak pengguna internet yang tertarik menggunakan aplikasi online dating, yaitu keinginan untuk mencari pasangan yang bertujuan dan memiliki ketertarikan yang sama, atau mencari pasangan yang memiliki ketertarikan yang sama sekali berbeda, sambil berusaha memisahkan diri dari orang-orang yang dianggap memiliki ketertarikan yang tidak menarik baginya deal breakers). Maka dari itu artikel ini membahas tentang komunikasi virtual yang dilakukan oleh komunitas Gay di internet atau media siber untuk tujuan eksistensi komunitas gay, menyampaikan hak-hak mereka sebagai komunitas gay, mengkampamyekan gaya hidup global yang negatif dan mengatakan bahwa Gay bukan perbuatan yang menyimpang. Hal ini menjadi persoalan di masyarakat karena Gay menjadi hal pro kontra karena tidak sesuai dengan nilai sosial, melawan martabat manusia dan ajaran Islam di Indonesia. Tetapi yang 
menjadi persoalan juga ada yang merujuk pada perilaku yang banyak dilakukan oleh kaum Nabi Luth AS, tetapi Nabi Luth AS termasuk perbuatan dosa besar yang dilaknat oleh Allah SWT. Zina dan perbuatan seks menyimpang lainnya seperti homoseks atau lesbian dipandang bertentangan dengan martabat dan naluri manusia yang beradab. Artikel ini membahas bagaimana proses komunikasi yang dilakukan oleh komunitas penyimpangan seksual yaitu kaum Gay yang dilakukan di dunia maya yaitu virtual community yang mereka anggap hal tersebut sebagi gaya hidup global.

\section{PEMBAHASAN}

Munculnya internet membawa peradaban baru yang mengubah banyak aspek kehidupan dan memberi tantangan berat bagi manusia dalam menghadapi realitas adanya komunitas Lesbi, gay, biseksual, transgender (LGBT). Perilaku homoseksual dalam kehidupan bertentangan dengan nilai-nilai agama maupun norma-norma susila. Perilaku ini dapat membawa efek negatif baik dari segi psikologis, moral dan kesehatan. Komunitas Gay ini melakukan komunikasi virtual di dunia siber dengan menggunakan internet untuk menjalin hubungan sosial. Hubungan sosial dengan melakukan negosiasi tentang peran gender pada forum online untuk mengasumsikan identitas yang mereka pilih sendiri sebagai komunitas virtual sesama kaum Gay dalam menciptakan realitas Gay di kalangan remajanya. Komunitas baru saat ini sudah tercipta dengan bentuk baru berupa komunitas virtual, tempat sosial yang tidak dapat dibantah, dalam hal ini orang tetap saling bertemu secara "tatap muka”, yang sebelumnya mereka jalin hubungan sosial melalui komunikasi komunitas secara virtual di meida cyber.

Komunitas Gay melakukan komunikasi dan hubungan sosial dengan sesama kaumnya Gay nya dilakukan secara intens di internet. Hal ini sesuai dengan teori yang dimunculkan oleh Lori Kendall yang berteori tentang komunitas dan internet. Komunitas sesama kaum penyimpangan seksual yaitu kaum Gay melakukan proses komunikasi secara inten di dunia maya secara virtual. Awalnya banyak fenomena tidak jelasnya sebuah komunitas atau eksistensinya diragukan, sama halnya seperti persoalan komunitas Gay dimana komunitas ini tidak jelas dan eksistensinya tidak diakui oleh masyarakat. Langkah-langkah yang dilakukan dalam aktivitas komunikasi komunitas virtual kaum Gay pertama adalah mendefinisikan komunitas virtual Gay ini, lalu merancang desain komunitas virtual Gay kedalam sebuah aplikasi di internet khususnya di media sosial dan untuk apa komunitas virtual Gay ini muncul. Tetapi ada juga pihak yang menganggap tidak berartinya sebuah komunitas di internet. Seperti kutipan Fernback dalam buku the handbook of internet studies:

\section{"Concept of online community has}

become increasingly hollow as it

evolves into a pastiche of elements

that ostensibly signify community". ${ }^{6}$

yang bisa diartikan dengan konsep komunitas online telah menjadi hampa karena berevolusi menjadi campuran dari unsur-unsur yang seolah-olah menandakan komunitas. Oleh karena ketidakjelasan dan 
sulit didefinisikan suatu komunitas, maka Fernback menawarkan pendekatan Interaksi simbolik untuk mengenal, mendefinisikan, bagaimana interaksi online antar komunitas dan menggambarkan konsep sebuah komunitas di internet khususnya adalah komunitas virtual.

Fernback menemukan bahwa peserta di kelompok online memiliki karakter unik pada hubungan sosial online. Disamping merespon, komunitas online juga bertindak untuk mengekspresikan rasa persatuan dan dukungan yang mereka alami dalam kelompok online mereka. Fernback juga menunjukkan bahwa aspek yang lebih penting dan sulit dipahami ialah komitmen7

Dalam teori komunitas dan internet dari Lori Kendall, menyatakan adanya ruang lingkup komunitas pada dunia internet. Dalam teori komunitas dan internet virtual community dari Lori Kendall, terdapat konseptual tentang komunikasi komunitas virtual yaitu:

1. Defining the Undefinable: Diartikan bahwa cara berkomunikasi di media siber atau internet untuk mendeteksi dan mendefinisikan apa yang sulit didefinisikan. Internet digunakan untuk mendefinisikan sebuah komunitas virtual Gay dan sesama anggota dalam komunitas tersebut saling berkomunikasi dan menjalin hubungan sosial dengan gaya hidup globalnya. Dengan ketidakjelasan konsep komunitas, dalam studi komunitas dan internet mengharuskan penulis menghadapi definisi ruang lingkup komunitas. Maka, untuk bisa mendefinisikan suatu komunitas, kita harus mencari tahu tentang apa saja dari dimensi ruang lingkup komunitas di media sosial, yaitu:
1. Bagian dari individual (an aggregation of individuals)

2. Berinteraksi dengan sekitarnya (interact around)

3. Berbagi ketertarikan (shared interest)

Sebuah komunitas di media sosial atau internet disebut komunitas virtual. Ketika sebuah komunitas virtual Gay melakukan komunikasinya dengan sesama komunitas virtualnya harus mendefinisikan terlebih dahulu dalam proses aktivitas komunikasi secara virtualnya tentang kondisi, keberadaan individu-individu yang masuk dalam komunitas virtual Gay tersebut misalnya komunitas virtual Gay yang dibuat dalam bentuk aplikasi Grindr. Harus dipastikan bahwa masing-masing individu yang menggunakan aplikasi Grindr ini betul-betul termasuk kaum Gay dengan penyimpangan seksualnya. Misalnya pengguna Grindr minimal sudah tujuh tahun menggunakan aplikasi ini, sejak pengguna Grindr berumur 15 tahun. Pengguna aplikasi Grindr banyak juga dari kalangan remaja yang berumur mulai dari 15 tahun. Pada kenyataannya remaja membentuk suatu virtual komunitas dengan mudah, walaupun ikatannya tidak sekuat dalam pembentukan komunitas yang nyata. Pengguna aplikasi ini mengetahui keberadaan aplikasi Gay ini dari artikel yang dimuat di internet dan ada juga dari info temannya. Pengguna menjadi penasaran dan mendownload aplikasi Grindr ini melalui Application store. Pengguna aplikasi Grindr ini mengaku ketagihan dengan aplikasi ini hingga mengaku pernah berinteraksi dengan semama Gay hingga pada level berhubungan intim dengan 
teman sesame Gay nya yang baru saja dikenalnya melalui aplikasi komunitas virtual Gay tersebut. Hal tersebut membuktikan bahwa komunikasi yang dilakukan sesama komunitas virtual di internet yakni komunitas Gay telah melakukan interaksi saling mengenal individu gay (an aggregation of individuals), telah melakukan interaksi dengan sekitarnya (interact around), hingga pada level terakhir saling berbagi ketertarikan satu sama lain sebelum mereka melakukan hubungan intim (shared interest). Inilah langkah proses mengetahui definisi dari yang terdefinisikan dalam online forum komunitas virtual Grindr.

Selanjutnya adalah cara mendesain atau merancang komunitas virtual Gay yang biasanya digunakan untuk mengungkap ruang lingkup komunitas. Terdapat lima karateristik dalam komunitas virtual yaitu:

a. Tujuan konten (Purpose of content)

Tujuan konten aplikasi Grindr digunakan untuk berkomunikasi sesama komunitas Gay di internet untuk mencari pacar sesama Gay dan untuk mencari teman kencan sesama Gay. Hal ini diperkuat dengan misi Grindr yaitu, "Grindr menghubungkan pria gay di seluruh dunia yang akan membawa kebahagiaan penggunanya. Perusahaan ini bertujuan untuk menjadi brand gaya hidup gay secara global terkemuka. Grindr secara bersamasama membawa pria gay dan masyarakat ke tempat dan hal-hal yang mereka sangat pedulikan. ${ }^{8}$ Adapun salah satu karakteristik pada media sosial ialah jaringan (network). Media sosial membentuk jaringan di antara penggunanya. Terlepas dari saling mengenal atau tidaknya pengguna di kehidupan nyata (offline). Jaringan inilah yang pada akhirnya membentuk komunitas atau masyarakat yang secara sadar maupun tidak, akan menghadirkan nilai-nilai dalam masyarakat virtual hingga pada struktur sosial secara online. Hal ini menunjukan bahwa tujuan konten (Purpose of content) media sosial Grindr ialah membentuk jaringan di antara penggunanya. Dikarenakan informan memahami tujuan dari konten Grindr sebagai media yang menghubungkan teman gay di mana saja. Dalam melihat komunitas virtual yang dibentuk oleh remaja, hendaknya bukan dari sisi ikatan waktu dan tempat, melainkan lebih kepada minat bersama dalam bidang social, budaya dan mental dari yang umum sampai dengan ke yang spesifik. Selama mempunyai anggota, bahasa dan pola interaksi, budaya dan kesamaan identitas, komunitas itu dapat dikatakan sebagai komunitas virtual. Komunitas virtual tidak akan pernah bisa menggantikan komunitas organic. Fungsinya hanya sebagai tambahan atau suplemen. Sebagai gambaran, aktivitas remaja dalam dunia maya hamper menghabiskan waktu mereka terlebih dengan adanya kecanggihan teknologi dan konvergensi media melalui handphone membawa mereka berinteraksi dengan internet lebih dari 12 jam dalam sehari.

\section{$b$. Tempat (extent of mediation)}

Pengguna komunitas virtual Grindr yaitu komunitas siber sesama Gay melakukan komunikasi di aplikasi tersebut dalam menentukan temoat bertemu dan tempat kencan sesame Gay itu dimana saja sesuai kesepakatan komunikasi sesame Gay. Faktanya janjian di isi aplikasi Grindr tersebut ketemu ada yang di Café, lalu hotel, 
atau langsung ketemuan ke rumah mereka Gay.

Pada teori Community dan Internet, sebagian besar masyarakat terhubung melalui internet melibatkan baik secara online maupun offline. Pada virtual community yang terutama adalah online, namun peserta juga sering berusaha untuk memenuhi pertemuan dengan peserta lain secara tatap wajah. 9 Hal ini menunjukan bahwa tempat (extent of mediation) pada media sosial Grindr mengikutsertakan pertemuan secara tatap wajah dengan pengguna lainnya.

c. Sistem desain (Platform)

Grindr memiliki beragam platform, diantaranya yaitu: pertama, Chat. Internet Relay Chat (IRC) merupakan layanan Internet yang memungkinkan untuk melakukan obrolan tertulis (chatting). Banyak orang melakukan chatting selama berjam-jam karena sangat mudah dan proses pengiriman atau penerimaan balasan yang cepat. Kedua, Global Positioning System (GPS). GPS adalah sistem navigasi menggunakan satelit yang didesain agar dapat menyediakan posisi secara cepat dan informasi hampir di semua tempat di muka bumi, setiap saat dan dalam kondisi cuaca apapun. Ketiga, headline. Headline adalah judul utama atau topik utama. Penggunaan headline harus menjadi pemicu yang menarik perhatian pengunjung, sehingga mereka akan terus mengunjungi atau membaca situs anda. Selain itu headline juga diharapkan mampu membuat penasaran pengunjung agar pengunjung ingin tau lebih banyak lagi mengenai diri anda. Keempat, general information. General information merupakan jenis data pribadi yang memungkinkan seseorang untuk mengidentifikasi atau menghubungi Anda, diantaranya nama, alamat, nomor telepon, alamat e-mail, data geo-lokasi, serta perangkat pengenal serta informasi non-publik lainnya tentang diri Anda. Karakteristik arsip pada media sosial, menjelaskan bahwa informasi telah tersimpan, informasi tidak hilang begitu saja dan mudah diakses kapanpun dan dimanapun. Dengan kemunculan teknologi komunikasi, arsip pada media sosial memberikan kemampuan pada penggunanya untuk mengakses dan mengubahnya sendiri. Serta, dijelaskan oleh Appadurai "the nature and distributions of its users”. Arsip di dunia maya tidak hanya dipandang sebagai dokumen resmi semata yang tersimpan. Arsip di internet tidak pernah benar-benar tersimpan, informasi selalu berada dalam jaringan, terdistribusi sebagai sebuah informasi dan menjadi mediasi antara manusia-mesin dan juga sebaliknya. ${ }^{10} \mathrm{Hal}$ ini menunjukan ketersediaan sistem desain (Platform) pada media sosial Grindr seperti chats, general information, GPS dan headline sebagai informasi yang terdistribusi dan memediasi. Baik antara sesama pengguna, maupun antara manusia dengan media sosial.

d. Pola interaksi (pattern of interaction)

Pola interaksi (pattern of interaction) pada media sosial Grindr seperti pada konsep simulacra yang melibatkan keterbukaan identitas sekaligus mengidentifikasi atau mengkontruk dirinya di dunia virtual. Interaksi yang biasanya di lakukan pengguna melalui akunnya, berawal dari chat. chatting ini disertai dengan 
mengirim foto asli pengguna. Dan apabila sudah saling mengirim foto asli diri dan tertarik, baik pengguna maupun lawan bicara biasanya langsung menanyakan "mau ketemu dimana?”. Selanjutnya, pengguna akan menyesuaikan tempat yang diinginkan untuk betemu. Pertemuan biasanya dilakukan pada saat itu juga, sesuai dengan tempat yang telah di janjikan. Dan pertemuan itu biasanya hanya sekedar untuk melakukan hubungan intim

e. $\quad$ Model keuntungan (Profit model) ${ }^{11}$

Model keuntungan (Profit model) pada media sosial Grindr adalah Global Positioning System (GPS). GPS memudahkan pengguna terhubung dengan teman gay lain dalam jarak terdekat. Media Grindr memberikan sarana kepada pengguna untuk saling berinteraksi, serta memiliki kebebasan dalam membentuk jaringan. Terdapat empat factor yang muncul sebagai karakter komunitas virtual, yaitu konteksnya eksternal, struktur yang tidak tetap, tujuan kelompok atau minat yang sama, dan karakteristik partisipannya. Jadi, selama keempat hal tersebut ada dalam interaksi mereka dan berlangsung terus-menerus, komunitas yang sifatnya virtualpun akan terwujud.

Jadi dalam aktivitas komunikasi virtual community di dunia maya sesama komunitas Gay remaja dengan wacana yang diungkapkan melalui interaksi mereka, muncul tiga karakter berikut, yaitu speech communities, discourse communities, dan communities of practices (Hymes, 1972 dan Cherny, 1999). Sementara dari sisi sosialnya, memunculkan adanya kepercayaan interpersonal, norma sosial, dan keanggotaan dalam suatu asosiasi yang dapat menentukan suatu komunitas. Latar belakang wacana, pengaruh dan faktor sosial memberi kontribusi terhadap pembentukan komunitas virtual. Komunitas virtual sesama kaum Gay remaja dengan sendirinya terbentuk bila didalamnya terdapat kepercayaan diantara mereka. Diawali dengan tersuratnya norma atau nilai yang mereka miliki dari ungkapan bahasa mereka gunakan serta keanggotaan remaja dalam suatu kelompok. Komunitas Virtual Gay remaja melakukan interaksi di dunia maya dengan aplikasi Grindr diwujudkan dalam bentuk isi, struktur, dan tujuan serta partisipasi mereka dalam berinteraksi, akhirnya melahirkan suatu kebersamaan dalam bentuk komunitas yang tidak secara langsung mereka deklarasikan. Artinya, remaja ini tidak mau dikatakan mempunyai komunitas virtual sendiri. Bagi mereka, remaja adalah komunitas mereka. Selama seorang remaja, siapapun dan dimanapun, akan bergabung dalam suatu topik pembahasan dan tidak keluar dari konteks yang sedang dibahas, maka itu sudah dianggap masuk dalam komunitas mereka. Dari karakteristik komunikasi virtual community diatas memunculkan suatu komunitas yang sifatnya Speech, Discourse dan Practice. Ketiga bentuk komunikasi komunitas virtual Gay di kalangan remaja ini tidak dapat dipisahkan satu sama lain karena masing-masing mempunyai karakteristik dan merupakan tahapan dalam membentuk komunitas.

\section{PENUTUP}

Pada dasarnya media sosial merupakan hasil dari perkembangan teknologi baru yang ada di internet dimana 
para penggunanya bisa dengan mudah untuk berkomunikasi, berpartisipasi, berbagi, dan membentuk sebuah jaringan di dunia virtual, sehingga para pengguna bisa menyebarluaskan konten mereka sendiri. Media sosial adalah medium di internet yang memungkinkan pengguna merepresentasikan dirinya maupun berinteraksi, bekerja sama, berbagi, berkomunikasi dengan pengguna lain dan membentuk ikatan sosial secara virtual.

Komunikasi yang terjadi pada komunitas virtual Gay seperti Grindr dengan tujuan menjalin hubungan sosial yang di mediasi oleh komunikasi melalui internet diantaranya adalah: pertama, purpose of content Grindr membentuk jaringan diantara pengguna dengan mencari pacar maupun teman kencan melalui Grindr. Kedua, extent of mediation dengan melakukan pertemuan secara tatap wajah di tempat yang telah di sesuaikan oleh antar pengguna. Diantara ketiga informan memilih dirumah sebagai tempat berinteraksi yang aman. Ketiga, Platform Grindr digunakan untuk mendistribusikan informasi diantaranya, yaitu: (a) chats yang digunakan untuk send message, send photo, send location, (b) profile untuk mencantumkan profile picture, display name, age (usia), headline (status pesan), (c) friends online untuk melihat pengguna lain yang sedang online Grindr, (d) favorites untuk melihat teman Grindr yang sering berinteraksi, (e) general information seperti: My Grindr tribes (tipe pengguna Grindr), height (tinggi), weight (berat badan), ethnicity (suku), body type (tipe badan), looking for (mencari hubungan), relationship status (status hubungan). Keempat, pattern of interaction melibatkan keterbukaan identitas sekaligus mengkonstruk diri di dunia virtual dengan cara: diawali dengan memilih pengguna lain sesuai kriteria pada tampilan home Grindr, kemudian chats menanyakan role (tipe homoseksual) apakah top (pria) atau bottom (wanita), yang kemudian dilanjutkan dengan pertemuan yang hanya sekedar untuk berhubungan seksual. Dari ketiga informan mengaku sering menggunakan Grindr hanya untuk kencan sesaat. Kelima, profit model GPS merupakan keuntungan bagi pengguna sebagai sarana agar lebih mudah untuk bertemu dengan pengguna Grindr lain.

Kaum Gay mayoritas dialami oleh kaum remaja mulai berumur dari 15 tahun keatas. Mereka menghabiskan waktu kisaran 12 jam lebih menggunakan internet mengakses apilkasi Grindr yaitu aplikasi sesama Gay yang menghubung seluruh dunia. Dengan adanya alokasi waktu yang mereka sedikan dalam dunia maya, komunitas remaja ini akan lahir dengan sendirinya. Pertama, mereka berada pada rentang usia yang hampir sama. Kedua, mempunyai minat pada pembicaraan yang setara. Hal ini terungkap karena jarang dan hampir tidak pernah mereka membicarakan hal-hal berat, seperti masalah politik dan ekonomi, tetapi lebih kepada masalah-masalah keseharian mereka, seputar sekolah, gaya hidup, teman dekat sesame Gay. Komunikasi virtual community diatas memunculkan suatu komunitas yang sifatnya Speech, Discourse dan Practice. Ketiga bentuk komunikasi komunitas virtual Gay di 
kalangan remaja ini tidak dapat dipisahkan satu sama lain karena masing-masing mempunyai karakteristik dan merupakan tahapan dalam membentuk komunitas.

\section{Catatan Akhir}

${ }^{1}$ Dr.Idi Subandy Ibrahim, M.Si dan Dr.Yosal Iriantara, Komunikasi yang Mengubah Dunia, (Bandung: PT Remaja Rosdakarya, 2017), h.102

2 Rulli Nasrullah, Media Sosial, (Bandung: Simbiosa Rekatama Media, 2015), h. 108

3 Jasmadi, Membangun Komunitas Online secara Praktis dan Gratis, (Jakarta: Elex Media Computindo, 2008), h. 16-17

4 Dian Budiargo, Berkomunikasi Ala Net Generation, (Jakarta, PT Elx Media

Komputindo, 2015), h.vi

5 Steve levin, "fact Sheet Grindr", diakses pada Juni 2015, dari www.grindr.com/press/

${ }^{6}$ Mia Consalvo dan Charless Ess, The

Handbook of Internet studies, P. 311

7 Mia Consalvo dan Charless Ess, The

Handbook of Internet studies, P. 310-311

${ }^{8}$ Steve Levin, Fact Sheet Grindr, diakses pada

Juni 2015 di www.grindr.com/press/

9 Mia Consalvo dan Charless Ess, The

Handbook of Internet studies, P. 320-321

${ }^{10}$ Rulli Nasrullah, Media Sosial, (Bandung:

Simbiosa Reka Utama, 2015), h. 34

${ }_{11}$ Mia Consalvo dan Charless Ess, The

Handbook of Internet studies, (United Kingdom:

Wiley-Blacwell, 2011), p.310

\section{DAFTAR PUSTAKA}

Budiargo, Dian, Berkomunikasi Ala

Net Generation, PT Elex Media

Komputindo, 2015

Consalvo, Mia, and Ess, Charless. The

Handbook of Internet studies.

United Kingdom: Wiley-Blacwell, 2011.

Creswell, J.W. Qualitative inquiry and research design: Choosing among five traditions. California: SAGE, 1998.

Frank Malcolm, Roehrig Paul dan Pring Ben, Apa yang harus dilakukan Budiargo, Dian, Berkomunikasi Ala Net Generation, PT Elex Media Komputindo, 2015

Consalvo, Mia, and Ess, Charless. The Handbook of Internet studies. United Kingdom: Wiley-Blacwell, 2011.

Creswell, J.W. Qualitative inquiry and research design: Choosing among five traditions. California: SAGE, 1998.

Frank Malcolm, Roehrig Paul dan Pring Ben, Apa yang harus dilakukan Ketika Mesin Melakukan Semuanya, Jakarta: PT Elex Media Komputindo, 2018

Jasmadi. Membangun Komunitas Online secara Praktis dan Gratis. Jakarta: Elex Media Computindo, 2008.

Kaplan, Anderas M., and Haenlein, Michael. User of the World, Unite! The Challenges and The Opportunities of social media. Paris: Business Horizons, 2010.

Maryono. Teknologi Informasi dan Komunikasi. Yogyakarta: Yudhistira Ghalia Indonesia. 2008. Nasrullah, Rulli. Teori dan Riset Media Siber (Cybermedia). Jakarta: Kencana, 2014. . Media Sosial.

Bandung: Simbiosa Rekatama Media, 2015. 
Savitri, Dewi. Manajemen Kesan

Kaum Gay Melalui Media Sosial

Grindr. Skripsi 'pada Universitas

Prof. Dr. Moestopo, 2015. Tidak

dipublikasikan.

Subandi Idi Ibrahim dan Iriantara

Yosal, Komunikasi yang

mengubah Dunia, Bandung:

Simbiosa Rekatama Media. 2017

Diakses dari www.grindr.com pada

Juni 2015. Diakses dari

www.grindr.com/press/pada Juni 2015 